\title{
ANAESTHESIA FOR LARYNGOSCOPY AND BRONCHOSCOPY IN CHILDREN
}

\section{Brian Kay, M D, Ff a R C S, and David Allan, M D *}

THE PRoBlems of anaesthesia for laryngoscopy and bjonchoscopy in children are well known, and have been reported extensively in a recent review of the subject, Austin ${ }^{1}$ summarized the wide range of conditions required by the surgeon and the many methods of providing for these conditions suggested by anaesthesiologists Austin points out the necessity of consideration of the surgeon's requirements when evaluating the suitability of any anaesthetic technique

When laryngoscopy or diagnostic bronchoscopy is the surgical procedure, most surgeons prefer unlimited access to the patient, and a view of the larynx and trachea uninterrupted by endotracheal tubes or catheters 'This necessitates either undepressed spontaneous respuration, or controlled respuration using a currasstype ventulator The latter method is on the whole unsatisfactory in children Obstruction of the airway (which is no longer under the control of the anaesthesiologist) prevents ventilation and is not obvious with the continued action of the currass A tight fit of the currass is often difficult to achieve over the wide range of sizes and body shapes encountered in children, and the changes of pressure in the cuirass frequently cause embarrassingly large movements of the surgical field in small children

The surgical requirements are further complicated when biopsy or therapeutic procedures such as removal of papillomata are to be performed A considerable time may be required for completion of these more extensive procedures, and the explosion hazard which exists with the presence of electrical connections and light bulbs is a major consideration should cautery or diathermy be required

Our technique is, therefore, designed to meet the most exacting of conditions to provide the surgeon with a patient who will breathe adequately, but quietly, withoul coughing, straining, or bronchospasm, throughout a lengthy procedure on the larynx or trachea, without danger of explosion It has fulfilled these requirements during a series of 41 cases over the last nine months, with an age range from 18 months to 13 years, the surgical procedure lasting up to 1 hour and 50 minutes In 30 cases the surgical procedure lasted for more than one-half hour (see Table I)

TABLE I

41 CASES

\begin{tabular}{lcc}
\hline & Average & Range \\
\hline Age (years) & $4 \frac{1}{2}$ & $1 \frac{1}{2}-13$ \\
Time for surgical procedure (min) & 38 & $6-110$ \\
Time for induction of anaesthesia (min) & 25 & $13-33$ \\
Satisfactory operating conditions after induction alone $-34(83 \%)$ \\
Supplementary anaesthesid required $-7(17 \%)$ \\
\hline
\end{tabular}

"Children's Memonal Hospital, Chicago, Illinoss 


\section{SELECTION OF METHOD}

Having established the necessity for undepressed spontaneous respiration through a lengthy period of surgical interference, we considered full topical anaesthesia a basic requirement The combination of local and general anaesthesia has been used widely and successfully for some years ${ }^{1,2,3}$ In our experience it is the only way of providing unencumbered surgical access to the patient, with adequate suppression of laryngeal and bronchial reflexes for periods of over 30 minutes

The choice of a general anaesthetic to cover this basic local anaesthetic has in most previous reviews been ether ${ }^{14}$ (though halothane has also been recommended $^{5}$ ) In reviewing the pharmacology of methoxyflurane (Penthrane), ${ }^{6}$ the clinical similarity to ether often impressed us, particularly the long time necessary for induction of anaesthesia and for recovery This long recovery time can be used to advantage and lengthy endoscopic procedures can be carned out during recovery from a prolonged methoxyllurane induction, ${ }^{*}$ achieving absorption of adequate amounts of the anaesthetic by body tissues This will allow the surgeon unrestricted access to the patient's airways and avoid the necessity of supplying anaesthetic gases to be blown into his face.

Other pharmacological aspects of methoxyflurane were considered The absence of flammability is essential for procedures requiring cautery and is advisable for others It also allows 100 per cent oxygen to be used as the carner gas during induction, an important factor in laryngeal or bronchospasm during initial manipulation of the larynx In comparison with other agents such as trichlorethylene or halothane, it is our clinical expenence that coughing and spastic reflexes during manipulation of the upper respiratory tract are much less common or severe with methoxyflurane anaesthesia, again a clinical similarity to ether Marked advantages over ether are the non-flammability and relatively small increase in salivary and bronchial secretion

The main pharmacological disadvantage of methoxyflurane is the respiratory depression occurring with deep anaesthesia For long procedures we have found it necessary to accept a small degree of underventilation, and limit the degree of saturation achieved should respiratory depression become more than slight A Wright respirometer can conveniently be used as a respiratory monitor during induction As the depth of anaesthesia decreases throughout the operation, so does any inital respuratory depression

\section{Method Evolved}

Having established the basic components of the method, detalls are tallored to suit the individual case and surgical procedure In general our method follows these lines

"Induction" throughout this paper is used to denote the period of deepening anaesthesia between the initiation of unconsciousness and the point where the surgeon is allowed to commence his work In almost all our cases the only anaesthesia given was the induction, and there was no "maintenance period" 
Premedication is usually confined to atropine only to dimmish respiratory depression Induction is mitiated by a sleep dose of thiopentone followed by nitrous oxade, oxygen, and methoxyflurane, usually with halothane added in the early stages to achieve rapid control of the patient The nitrous oxide and halothane are withdrawn after a few minutes, and oxygen and methoxyflurane given untul the jaw is relaxed

Topical anaesthesia of the operative area is then produced Achrevement of the very good local anaesthesia basically necessary for this technique requires maximal utilization of the small amounts of local anaesthetic avalable without running the risk of a toxic reaction $\mathrm{A}$ meticulous technique providing accurate placement of suitable quantities through a fine spray is essential We use 4 per cent lignocame in a dose of $5 \mathrm{mg} / \mathrm{kg}$ body weight ${ }^{\top}$ This quantity is accurately measured into the chamber of a Conn or Swerdlow laryngeal spray and applied progressively in two or three stages at a few minutes' interval This serves to prevent the inhalation of large quantities which could produce high blood levels, and reduce reflexes by allowing the early applications to produce anaesthesia before advancing the laryngoscope and spray $\mathrm{A}$ uniform distribution of the lignocame over the following sites in this order is achieved (1) base of tongue, (2) upper surface of epiglottis, (3) pyriform fossae, (4) larynx generally, then each vocal cord separately, posterior then anterior commissure, (5) lower surface of epiglottıs, (6) trachea

Definitive local anaesthesia of the carina and bronchi is not generally sought in order to maintain the safety factor of cough in the event of inhalation of blood or mucus to these levels

After application of the local anaesthetic, methoxyflurane is administered as rapidly as possible until the required degree of saturation is achieved As a rough guide, 20 minutes of good operating conditions will require a total induction time of 20 minutes, using 15 per cent methoxyflurane, but further increases in inducton time produce a relatively longer increase in operating time, often with the appearance of slight respiratory depression Should respuatory depression appear, the induction is ended

As soon as induction is complete the surgeon may take over access to, and control of the aurways, and further anaesthesıa is 1arely required Should the length of time requured for the operation be seriously underestimated, or induction have been curtailed by respiratory depression, a further few minutes of methoxyflurane inhalation through a mask or endoscope may be necessary, and will re-establish satısfactory operating conditions and allow a further period of operating time

\section{SUMMARI}

Some of the optumal surgical requirements for anaesthesia for bronchoscopy and laryngoscopy in children are considered Some limitations of several previously suggested methods of anaesthesia are observed, and a means of producing the required operating conditions suggested, using anaesthetic agents with the most suitable pharmacological properties It is suggested that anaesthesia of the 
larynx and trachea is best produced by precise topical applications of 4 per cent lignocaine, and unconsciousness best provided by the recovery penod following induction with methoxyflurane

\section{RÉSUMÉt}

Les problèmes de l'anesthésie pour la laryngoscopie et la bronchoscopie chez les enfants sont bien connus et ont été exposés longuement La plupart des chururgiens préfèrent un accès sans obstacle aux malades, une vue du larynx et de la trachée non obstruée par dès tubes endotrachéaux ou des cathéters Les exıgencies chirurgicales deviennent encore plus compliquées lorsqu'il faut pratıquer une biopsie ou des traitements tels que l'exérèse de papillomes Le risque d'explosion qui apparaît avec la présence de raccordements et d'ampoules électriques devient d'une importance capitale Ein conséquence, notre technique dort pouvoir présenter un malade qui respire adéquatement mais calmement, sans tousser, sans efforts nı bronchospasme, pour la durée d'une longue opération sur le larynx ou la trachée, tout en demeurant à l'abrı des explosions Au cours d'une série de 41 cas, d'une durée allant jusqu'à 1 h 50, nous avons pu rencontrer ces exigences

Habituellement, la prémédıcation se résume à l'atropıne, afin d'éviter toute dépression respiratoire. Nous faisons l'induction avec une dose hypnotique de thiopentone suivie de protoxyde d'azote-oxygène et de méthoxyflurane, aux stades de début, nous ajoutons de l'halothane, pour obtenır un contrôle rapıde du malade Au bout de quelques minutes, le protoxyde et l'halothane sont supprimés et l'on contınue d'administrer de l'oxygène et du méthoxyflurane jusquà ce que le mandibule soit relâché

On pratique une anesthésie locale du site opératorre avec de petites quantités d'anesthésique local sans risquer de produre des réactions toxiques Nous employons de la lignocaine 4 pour cent à la dose de $5 \mathrm{mg} / \mathrm{kg}$ de poids corporel L'application est faite en deux ou trois reprises à quelques minutes d'intervalle

Après l'application de l'anesthésique local, on administre le méthoxyflurane aussi rapidement que possible jusqu'à l'obtention du degré de saturation désirée De façon approximative, pour procurer 20 minutes de bonnes conditıons opératoires, 1 faut une durée totale d'induction de 20 minutes et employer une concentration de 15 pour cent de méthoxyflurane Il faut arrêter l'induction dès qu'une dépression respiratoire se manifeste

Dès que l'induction est complète, le chirurgien peut avoir accès aux voies respiratoures et en prendre le contrôle, et l'opération se pratıque au cours de l'élimination de l'anesthésie au méthoxyflurane Il est rare qu'on doive ajouter de l'anesthésıe, toutefors, au besoin, on peut faire unhaler de nouveau du méthoxyflurane durant quelques minutes au moyen d'un masque ou de l'endoscope et lon obtiendra des conditions opératorres satisfarsantes

\section{REFERENCES}

1 Austin, S Anaesthesia for Bronchoscopy and Bionchography in Children Anesth \& Analg Curr Res 42623 (1963)

2 Macintosh, R R Anaesthesia for Bronchoscopy Anaesthesia 977 (1954) 
3 Carnes, M A, \& Fabian, L W Anaesthesia for Bronchoscopy and Bronchography Anesth \& Analg Curr Res 40567 (1961)

4 SMrth, $R$ M Anaesthesia for Infants and Children, 2nd ed, p 341 St Lous C V Mosby Co (1963)

5 Brown, D Halothane-Oxygen Anaesthesia for Bronchoscopy in Children Anaesthesia 14 135 (1959)

6 Artusio, J F JR et al Clinical Evaluation of Methoxyflurane in Man Fed Proc 19273 (1960)

7 Bromage, P R, \& Rosson, J G Concentration of Ligncicame in the Blood after Intravenous, Intramuscular, Epidural and Endotracheal Adminıstration Anaesthesia $16 \quad 461$ (1961) 